\title{
COMMENTARY
}

\section{Where have all the direct-marketing farms gone? Patterns revealed from the 2017 Census of Agriculture}

\author{
Jeffrey K. O’Hara ${ }^{a *}$ and Matthew C. Benson ${ }^{b}$ \\ United States Department of Agriculture
}

Submitted June 6, 2019 / Accepted August 7, 2019 / Published online August 23, 2019

Citation: O'Hara, J. K., \& Benson, M. C. (2019). Where have all the direct-marketing farms gone?

Patterns revealed from the 2017 Census of Agriculture. Journal of Agriculture, Food Systems, and

Community Development, 9(1), 31-37. https://doi.org/10.5304/jafscd.2019.091.046

Copyright (C) 2019 by the Author. Published by the Lyson Center for Civic Agriculture and Food Systems. Open access under CC-BY license.

\begin{abstract}
Food system researchers and practitioners have used the U.S. Census of Agriculture historically as a bellwether to measure changes in the directmarketing sector. The U.S. Department of Agriculture has made considerable improvements in measuring this sector in recent years, which formed the basis for the phrasing of the 2017 Census of Agriculture direct-marketing questions. While the new questions make it challenging to infer directmarketing trends between 2012 and 2017, the 2017
\end{abstract}

a $*$ Corresponding author: Jeffrey K. O'Hara, U.S. Department of Agriculture Agricultural Marketing Service; 1400 Independence Ave. SW, Room 4509-S; Washington, DC 20250-0269 USA; +1-202-756-2575; jeffreyk.ohara@usda.gov

b Matthew C. Benson, U.S. Department of Agriculture Food and Nutrition Service; 3101 Park Center Drive; Alexandria, Virginia 22302 USA; +1-703-305-2556;

matthew.benson@usda.gov

\section{Disclaimer}

The views expressed are those of the authors and should not be attributed to the U.S. Department of Agriculture.
Census of Agriculture data nonetheless reveals a considerable decline in the number of farms selling directly to consumers and wholesalers in the U.S. We discuss possible explanations for this decline and implications for the direct-marketing sector.

\section{Keywords}

Local Foods, Census of Agriculture, Direct-to-

Consumer Agricultural Sales

\section{Introduction}

A principle use of U.S. Census of Agriculture data is to ascertain farm-sector trends. The 2017 Census of Agriculture provides greater insight into direct marketing than historical estimates and reflects improvements that the U.S. Department of Agriculture (USDA) has made in measuring the sector. Hereafter, we refer to "direct-marketing" activity generically to include "direct-to-consumer" transactions (e.g., farm sales at farmers markets) and "direct wholesale" transactions (e.g., farm sales to restaurants). Measuring changes in market conditions over time is valuable for several reasons, since 
it can inform where policy support may have been most impactful and emerging market opportunities for farms. However, the change in direct-marketing questions between the 2012 and 2017 surveys makes it impossible to compare trends in market sales. Despite these changes, examining trends in the number of farms doing direct marketing is still possible. In this commentary, we demonstrate that the 2017 Census of Agriculture reveals a considerable decline in the number of farms selling directly to consumers and wholesalers in the U.S. relative to 2012. We discuss where these changes are most pronounced, as well as possible reasons for and implications of these trends.

\section{Census of Agriculture and Direct Marketing: Methodological Issues}

\section{Census of Agriculture: 1978-2012}

The Census of Agriculture is administered by the USDA every five years. The objective of the Census of Agriculture is to survey all places in which US $\$ 1,000$ worth of agricultural products were potentially produced and sold. In 2017, USDA estimated that there were about three million potential farms. Of these, $72 \%$ completed the census forms. Thus, the Census of Agriculture provides unique insights into the U.S. farm economy that are not available through other sources.

Beginning with the 1978 Census of Agriculture, farms were instructed to report sales of edible products at direct-to-consumer (DTC) agricultural outlets (Figure 1). DTC sales are those occurring via roadside stands; farmers markets; community supported agriculture (CSA) programs; on-farm stores; and, in more recent years, online marketplaces. Farms were instructed to report only direct sales of unprocessed farm products like fresh fruit, fresh vegetables, milk, and eggs. They were instructed to exclude sales of non-edible products (like craft items), resold products, farm products produced off-farm, and sales of value-added products that were processed on-farm. This phrasing implies that sales of, for instance, meat, cider, wine, cheese, butter, jelly, jam, and salsa were not to be reported in the DTC sales estimate. This was the only direct-marketing sales question included in the Census of Agriculture through 2012.

Evidence collected from other USDA surveys suggested that direct-marketing sales were occurring predominately via direct wholesale market channels (Low et al., 2015; Low \& Vogel, 2011). To generate more information about the use of direct wholesale channels, a yes/no question was added to the 2012 Census of Agriculture that asked farms if they marketed products directly to retailers that in turn sell directly to consumers.

\section{Local Food Marketing Practices Survey: 2015}

USDA administered the first-ever Local Food Marketing Practices Survey (LFMPS) in 2016 (to collect 2015 data) to solicit detailed information about market channels used by direct-marketing farmers (USDA NASS, 2019a). The LFMPS was the first USDA survey to collect sales data of value-added agricultural products that were

\section{Figure 1. 2012 Census of Agriculture Questions}

\section{SECTION 33 DIRECT SALES FOR HUMAN CONSUMPTION}

1. During 2012 , did you produce, raise, or grow any crops, livestock, poultry, or agricultural products that were sold directly to individual consumers for human consumption?

INCLUDE - sales from

- roadside stands

- farmers markets

- pick your own

- door to door, etc. EXCLUDE - craft items

- processed products such as cheese

- Community Supported Agriculture (CSA) - wine and cider

1409

Yes - Gross value of these direct sales Specify product(s) $\stackrel{1410}{\rightarrow}$

3

\section{No - Go to SECTION 34}


processed on-farm and direct sales by farms to retail establishments, institutions, and other local intermediary businesses like food hubs. Even though the LFMPS contains the phrase "local" in the title, there are no geographic restrictions on sales. In particular, the DTC sales estimate includes online sales by farmers, which conceivably can occur across any distance.

We compare the methodologies between Census of Agriculture and LFMPS, since the Census of Agriculture's direct-marketing questions were changed between 2012 and 2017 based on the LFMPS's design. However, comparing data between the Census of Agriculture and LFMPS must be undertaken cautiously due to the different ways they were administered. While the former is a census of all known farms, the latter is a sample of direct-marketing farms. USDA used responses from approximately 5,700 farms to generate aggregate LFMPS 2015 sales estimates (O'Hara \& Lin, 2019). Since this was the first time USDA administered the LFMPS, the list of potential respondents may have been incomplete. While Census of Agriculture data is publicly available at the county level, USDA only released state-level estimates from the LFMPS for 30 states; it did not disclose data at the county level due to both a lack of data and privacy concerns.

Census of Agriculture: 2017

Questions in the 2017 Census of Agriculture regarding direct marketing were designed to mimic the more comprehensive questions in the LFMPS. This rephrasing of the pre-existing questions restricts the ability of stakeholders to evaluate trends in direct-marketing activity between 2012 and 2017. However, the 2017 data represents a far more comprehensive estimate of the sector. While the new questions introduce a one-time transition that complicates the ability to infer trends between 2017 and previous years, these changes will provide more information and likely improve the capability of stakeholders to analyze direct-marketing trends in future years.

The 2017 DTC sales question was reworded so that farms reported the aggregated sales of both unprocessed farm products (such as fresh fruits and vegetables) and value-added products processed on-farm (such as cider and jelly) (see Figure 2). This means that the DTC sales estimates

\section{Figure 2. 2017 Census of Agriculture Questions}

\section{SECTION 26 FOOD MARKETING PRACTICES}

1. During 2017, did this operation produce and sell any crops, livestock, poultry, or agricultural products that were food for humans to eat or drink?

INCLUDE

for human consumption $\quad$ - commodities produced under production contracts

- products purchased and resold

2750

$\square$ Yes - Complete this section

$3 \square$ No - Go to SECTION 26

2. How much was received in 2017 for the food produced and sold directly to:

a. Consumers: Farmers markets, on-farm stores or farm stands, roadside stands or stores, u-pick, CSA (Community Supported Agriculture), online marketplaces, etc.?

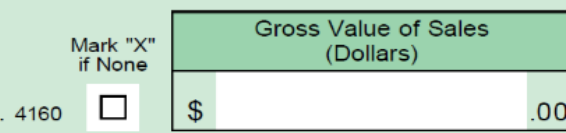

(i) Specify the food(s) that was produced and sold directly to consumers in 2017.

4161

b. Retail Markets, Institutions, or Food Hubs for Local or Regionally Branded Products: Supermarkets, supercenters, restaurants, caterers independently owned grocery stores, food cooperatives, $\mathrm{K}-12$ schools, colleges or universities, hospitals, workplace cafeterias, prisons, foodbanks, etc.?

(i) Specify the food(s) that was produced and sold directly to retail markets, institutions, or food hubs in 2017.

2751

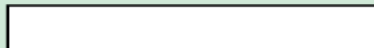


Table 1. Summary Table of Direct-marketing Questions in the Census of Agriculture in 2012 and 2017

\begin{tabular}{|c|c|c|c|}
\hline Market Channel & & 2012 & 2017 \\
\hline \multirow{3}{*}{ Consumers } & $\begin{array}{l}\text { Market channel } \\
\text { examples provided }\end{array}$ & $\begin{array}{l}\text { Roadside stands, farmers } \\
\text { markets, pick your own, } \\
\text { door-to-door, CSA }\end{array}$ & $\begin{array}{l}\text { Roadside stands or stores, farmers } \\
\text { markets, on-farm stores or farm stands, } \\
\text { CSA, online marketplaces }\end{array}$ \\
\hline & $\begin{array}{l}\text { Report gross value of } \\
\text { sales }\end{array}$ & Yes & Yes \\
\hline & $\begin{array}{l}\text { Include On-Farm } \\
\text { Processed Products }\end{array}$ & No & Yes \\
\hline \multirow{4}{*}{ Direct Wholesale } & Definition & $\begin{array}{l}\text { Market products directly to } \\
\text { retail outlets that in turn } \\
\text { sell directly to consumers }\end{array}$ & $\begin{array}{l}\text { Sales to retail markets, institutions, or } \\
\text { food hubs for local or regionally branded } \\
\text { products }\end{array}$ \\
\hline & $\begin{array}{l}\text { Market channel } \\
\text { examples provided }\end{array}$ & $\begin{array}{c}\text { Restaurants, grocery stores, } \\
\text { schools, hospitals, or other } \\
\text { businesses }\end{array}$ & $\begin{array}{l}\text { Supermarkets, supercenters, restaurants, } \\
\text { caterers, independently owned grocery } \\
\text { stores, food cooperatives, K-12 schools, } \\
\text { colleges or universities, hospitals, work- } \\
\text { place cafeterias, prisons, foodbanks }\end{array}$ \\
\hline & $\begin{array}{l}\text { Report gross value of } \\
\text { sales }\end{array}$ & No & Yes \\
\hline & $\begin{array}{l}\text { Include on-farm } \\
\text { processed products }\end{array}$ & N.A. & Yes \\
\hline
\end{tabular}

Note: Farmers are instructed to only report sales of edible agricultural products produced on-farm.

This excludes non-edible products, products bought and resold, and products not grown/raised on operation.

in the 2017 Census of Agriculture are not comparable to DTC sales data from previous versions of the Census of Agriculture. Also, a new question was inserted into the 2017 Census of Agriculture asking farms to report sales they made to retail markets, institutions, or food hubs of locally or regionally branded products. (The question did not define what constituted a "branded" product.)

Despite these changes to the questions regarding sales, trends between 2012 and 2017 in the number of direct-marketing farms can be still inferred because the count for both DTC farms and direct wholesale farms in the 2017 Census of Agriculture is more expansive. First, DTC farms that undertook value-added production exclusively and did not make any sales of unprocessed farm products would not have been counted in the 2012 Census of Agriculture, but they would be counted in 2017. Second, in 2012, the phrasing of the direct wholesale question suggests that sales through locally oriented distributors, like food hubs, should not be included. This is because consumers are unlikely to make purchases directly from food hubs. In 2017, direct wholesale farms were asked to include food hub sales provided that the product was locally or regionally branded. We summarize these changes in the Table 1.

If there were a greater number of directmarketing farms in 2017 than in 2012, then it would be unclear if the change was attributable to changes in the phrasing of the question or overall sector trends. However, if there were fewer directmarketing farms in 2017 than in 2012, we could conclude a decline had occurred because the phrasing of questions was less restrictive in 2017.

\section{Direct-marketing Farm Trends}

We show in Table 2 that DTC sales of unprocessed products approximately doubled in the U.S. between 1992 and 2007 from US\$706 million to US $\$ 1.4$ billion (in 2017 U.S. dollars). Similarly, the number of DTC farms rose by over 50 percent between 1992 and 2007 (from 86,432 to 136,817). DTC sales plateaued between 2007 and 2012. The 2015 LFMPS revealed that value-added products accounted for $47 \%$ of total DTC sales. Aggregate DTC sales appear to have declined by $10 \%$ between 2015 (US\$3.1 billion) and 2017 (US\$2.8 billion), although this interpretation is subject to the caveat we mentioned earlier regarding comparing LFMPS and Census of Agriculture data. 
Table 2. Direct-to-Consumer (DTC) Farms and Sales for Commodities and Value-added Products, 1992-2017

\begin{tabular}{|c|c|c|c|c|c|c|c|}
\hline \multirow[b]{2}{*}{ Year } & \multirow[b]{2}{*}{ Survey } & \multicolumn{3}{|c|}{ DTC Farms } & \multicolumn{3}{|c|}{ DTC Sales (billion 2017 USD) } \\
\hline & & $\begin{array}{l}\text { Unprocessed } \\
\text { Products }\end{array}$ & $\begin{array}{l}\text { Processed } \\
\text { Products }\end{array}$ & $\begin{array}{l}\text { Processed and } \\
\text { Unprocessed }\end{array}$ & $\begin{array}{l}\text { Unprocessed } \\
\text { Products }\end{array}$ & $\begin{array}{l}\text { Processed } \\
\text { Products }\end{array}$ & $\begin{array}{c}\text { Processed and } \\
\text { Unprocessed }\end{array}$ \\
\hline 1992 & Ag. Census & 86,432 & & & $\$ 0.7$ & & \\
\hline 1997 & Ag. Census & 93,140 & & & $\$ 0.9$ & & \\
\hline 2002 & Ag. Census & 116,733 & & & $\$ 1.1$ & & \\
\hline 2007 & Ag. Census & 136,817 & & & $\$ 1.4$ & & \\
\hline 2012 & Ag. Census & 144,530 & & & $\$ 1.4$ & & \\
\hline 2015 & LFMPS & 58,560 & 74,738 & 114,801 & $\$ 1.7$ & $\$ 1.5$ & $\$ 3.1$ \\
\hline 2017 & Ag. Census & & & 130,056 & & & $\$ 2.8$ \\
\hline
\end{tabular}

The number of DTC farms decreased from 144,530 in 2012 to 130,056 in 2017, even though the 2017 estimate includes farms exclusively selling value-added products. This suggests that the decline in DTC farms during this period was at least $10 \%$. In Table 3, we present state-level results for 20 states with the greatest number of DTC farms in 2017. There was a decline of at least 3,000 DTC farms in the West Coast states of California, Oregon, and Washington. There was likewise a decline of at least 1,800 DTC farms in the midAtlantic states of New York and Pennsylvania. The combination of these states represents two of the most prominent regions of the country for DTC marketing (Low et al., 2015). Only four of the 20 states that had the greatest number of DTC farms in 2012 did not experience an unambiguous decline in DTC farms between 2012 and 2017. Three of these states are in a contiguous region of the Southeast (Kentucky, Virginia, and Tennessee).

The reduction in direct wholesale farms from 49,043 in 2012 to 28,958 in 2017 was more pronounced than the decline in DTC farms (Table 4). Since the 2017 question was broader, this represents a decline of at least $41 \%$. The decline of at least $81 \%$ in Texas is particularly pronounced, since in 2012 the state had the second-highest number of direct wholesale farms in the 
U.S. Of the 20 states in the U.S. with the most direct wholesale farms, only two (California and Florida) may have experienced declines of less than $20 \%$.

In Figure 3, we show that the proportion of smaller-sized farms engaged in DTC marketing was greater in 2017 than in 2012. In 2017, $30 \%$ of DTC farms had a size of fewer than 10 acres (4 hectares). In 2012, $23 \%$ of DTC farms were this small. Similarly, there was a greater number of smaller-sized DTC farms in 2017 than in 2012. This figure suggests that the decline in DTC farms during this period was driven by a reduction in larger farms.

While it is possible that some larger DTC farms decided to make direct-marketing sales exclusively through direct wholesale channels, the corresponding decline in direct wholesale farms indicates that in the aggregate this is unlikely to be the sole explanation. Crop prices were relatively lower in 2017 than in 2012, and as a result, it would not necessarily have been advantageous for direct-marketing farms to have begun producing commodity crops like corn and soybeans during this period (USDA NASS, 2019b). We cannot compare changes in the size distribution of direct wholesale farms between 2012 and 2017 because this information was not reported in the 2012 Census of Agriculture.

\section{Discussion and Conclusions}

Data from the Census of Agriculture reveals there was an unambiguous decline in the number of direct-marketing farms between 2012 and 2017. Since the phrasing of the questions in the Census of Agriculture was broader in 2017 than in 2012,
Table 4. Change in Number of Direct Wholesale Farms, 2012 to 2017, for the 20 States with the Highest Number of Direct Wholesale Farms in 2012

\begin{tabular}{lrrrrr}
\hline State & $\mathbf{2 0 1 2}$ & $\mathbf{2 0 1 7}$ & Change & \% Change & 2012 Rank \\
\hline California & 4,432 & 4,301 & -131 & $-3 \%$ & 1 \\
New York & 2,533 & 1,587 & -946 & $-37 \%$ & 3 \\
Pennsylvania & 2,379 & 1,443 & -936 & $-39 \%$ & 4 \\
Wisconsin & 1,719 & 1,153 & -566 & $-33 \%$ & 9 \\
Washington & 1,654 & 1,142 & -512 & $-31 \%$ & 10 \\
Oregon & 1,898 & 1,040 & -858 & $-45 \%$ & 6 \\
Michigan & 1,637 & 1,029 & -608 & $-37 \%$ & 11 \\
Florida & 1,187 & 982 & -205 & $-17 \%$ & 14 \\
Ohio & 1,802 & 962 & -840 & $-47 \%$ & 7 \\
North Carolina & 2,201 & 925 & $-1,276$ & $-58 \%$ & 5 \\
Hawaii & 1,260 & 878 & -382 & $-30 \%$ & 13 \\
Virginia & 1,769 & 828 & -941 & $-53 \%$ & 8 \\
Maine & 1,074 & 795 & -279 & $-26 \%$ & 17 \\
Vermont & 1,174 & 737 & -437 & $-37 \%$ & 15 \\
Missouri & 923 & 699 & -224 & $-24 \%$ & 21 \\
Minnesota & 974 & 637 & -337 & $-35 \%$ & 20 \\
Kentucky & 1,341 & 615 & -726 & $-54 \%$ & 12 \\
Texas & 2,927 & 569 & $-2,358$ & $-81 \%$ & 2 \\
Massachusetts & 1,035 & 567 & -468 & $-45 \%$ & 18 \\
lowa & 914 & 558 & -356 & $-39 \%$ & 22 \\
\hline Total & 49,043 & 28,958 & $-20,085$ & $-41 \%$ & \\
\hline Question phas & & & & & \\
\hline
\end{tabular}

Question phrasing varied between 2012 and 2017.

Each state has a statistically significant difference at the 0.01 level.

only a lower limit on the decline between 2012 and 2017 is known. The different questions further imply it is challenging to investigate the causes of the decline with the data. One factor that could have contributed to a national-level decline in direct-marketing farms is an increase in online shopping. If online purchases had an adverse impact on brick-and-mortar retailers, retailers may have been less inclined to have made purchases from nearby farms, which in turn could decrease the number of direct wholesale farms. Online purchasing could similarly have adversely affected DTC producers. Since direct marketing is particularly advantageous to farms near cities (e.g., O'Hara \& Lin, 2019), development pressures associated with urban expansion like sprawl or increased land prices could have been disadvantageous to directmarketing farms in urban areas.

Practitioners and researchers with highly informed views of their own direct market conditions may be able to undertake more in-depth 


\section{Figure 3. Comparison in the Size of Farms Selling Direct to Consumer (DTC) in 2012 and 2017 Censuses of Agriculture}

The number of DTC farms in each category appears on each section of the chart.

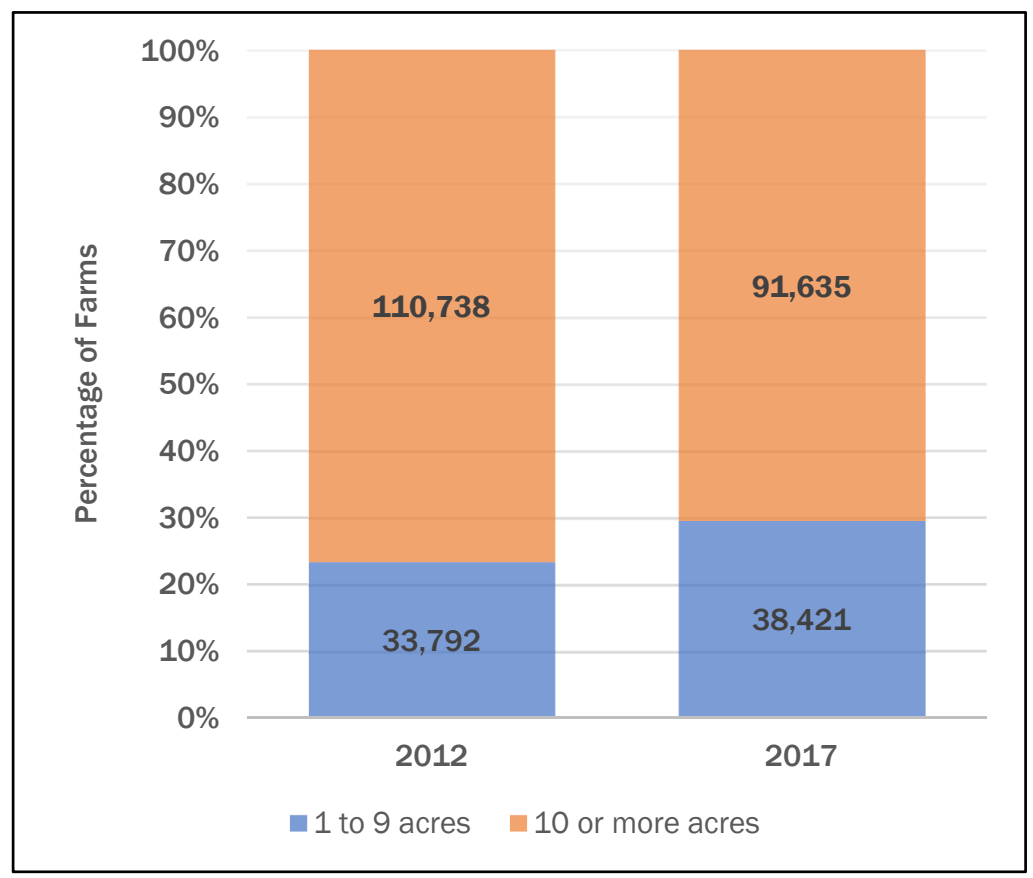

Source: U.S. Department of Agriculture, National Agricultural Statistics Service, 2019c. Note: 1 acre $=0.4$ hectare studies that can identify causes behind this trend. Additionally, organizations administering technical assistance programs geared toward direct-marketing farmers may want to examine their activities to see which ones are most effective at mitigating this decline in the number of farms doing direct marketing.

\section{References}

Low, S. A., Adalja, A., Beaulieu, E., Key, N., Martinez, S., Melton, A., . . Jablonski, B. B. R. (2015). Trends in U.S. local and regional food systems: A report to Congress (Administrative Publication No. AP-068). Washington, D.C.: U.S. Department of Agriculture, Economic Research Service. Retrieved from https://www.ers.usda.gov/publications/pub-details/?pubid $=42807$

Low, S. A., \& Vogel, S. (2011). Direct and intermediated marketing of local foods in the United States (Economic Research Report No. 128). Washington, D.C.: U.S. Department of Agriculture, Economic Research Service. Retrieved from https://www.ers.usda.gov/webdocs/publications/44924/8276_err128_2_.pdf

O'Hara, J. K., \& Lin, J. (2019). Population density and local food market channels. Applied Economic Perspectives and Policy, ppy040. https://doi.org/10.1093/aepp/ppy040

U.S. Department of Agriculture, National Agricultural Statistics Service (USDA NASS). (2019a). Local food marketing practices survey. Retrieved May 9, 2019, from https://www.nass.usda.gov/Publications/AgCensus/2012/Online Resources/Local Food/index.php

USDA NASS. (2019b). Prices paid and received: Crop farm index by month, US [Chart]. Retrieved May 14, 2019, from https://www.nass.usda.gov/Charts_and_Maps/Agricultural_Prices/cropfarm.php

USDA NASS. (2019c). Census of Agriculture. Retrieved August 19, 2019, from https:/ /www.nass.usda.gov/AgCensus/ 